\title{
CECROPIACEAE A NEW FAMILY OF THE URTICALES
}

\author{
C.C. Berg*
}

\section{Summary}

The problem of the correct position of the Conocephaloideae, a subfamily of the Moraceae in Engler's system, but transferred to the Urticaceae by Corner (1962), can be satisfactorily solved by assigning the rank of family to this taxon, to be named Cecropiaceae. Diagnoses of and a key to the six genera constituting this family (Cecropia, Coussapoa, Musanga, Myrianthus, Poikilospermum, and Pourouma) are given. The classification of the Urticales and the relationship between the Cecropiaceae and both Moraceae and Urticaceae are discussed. A key to the families of the Urticales is given.

Cecropiaceae C.C. Berg fam. nov.

Type genus: Cecropia Loefling

Cecropieae Gaudichaud in Freycinet, Voy. Uranie, Bot. 491, 506. 1830, as tribe of the Urticeae (= Urticales)

Pouroumeae Gaudichaud in Freycinet, Voy. Uranie, Bot. 491, 511. 1830, as tribe of the Urticeae (=Urticales); Trécul, Ann. Sci. Nat. Bot. III. 8: 77. 1847, as tribe of the Artocarpeae (= Moraceae s.l., p.p.); Miquel in Martius, F1. Bras. 4 (1): $83,122.1853$, as subtribe of the Artocarpeae (= Moraceae s.l., p.p.).

Conocepbaleae Trécul, Ann. Sci. Nat. Bot. III. 8: 77. 1847, as tribe of the Artocarpeae (= Moraceae s.l., p.p.); Miquel in Martius, Fl. Bras. 4 (1); 83, 131. 1853, as subtribe of the Artocarpeae (= Moraceae s.l., p.p.); Bureau in De Candolle, Prodr. 17: 280, 283. 1873, as tribe of the Artocarpaceae (=Moraceae s.l., p.p.); Bentham \& Hooker, Gen. Pl. 3 (1): 343. 1880, as tribe of the Urticaceae (= Urticales).

Conocephaloideae Engler in Engler \& Prantl, Nat. Pflanzenfam. 3 (1): 93. 1889 , as subfamily of the Moraceae sensu Engler, transferred to the Urticaceae by Corner, Gard. Bull. Singapore 19: 251.1962.

For a historical review of the subdivisions of the Urticales the reader is referred to Chew Wee-Lek, Gard. Bull. Singapore 20 (1): 22.1963.

Arbores vel frutices semper dioeci, radicibus aeriis vel gralliformibus; systema ductuum laticiferorum reductum, laticem haud exudans. Folia spiraliter disposita, integra vel plus minusve profunde palmato- vel radiato-incisa; stipulae connatae. Inflorescentiae cymoso-ramosae vel capitatae vel glomerulum digitatum spicarum efformantes. Flores staminati tepalis 4-2, liberis vel connatis; stamina 4-1, recta, interdum inflexa et gradatim porrigentia, sed non elastice eflectentia; pistillati tepalis 4-2, connatis; stigma ligulatum, capitato-penicillatum vel peltatum; ovulum (sub)orthotropum, basale vel subbasale; semen parvum vel magnum; embryo simplex, rectus; endospermum adest vel abest.

Terrestrial or hemi-epiphytic woody plants with aerial roots or stilt-roots and with a reduced system of latex tubes. Leaves spirally arranged, pinnately veined to subtriplinerved or to palmately veined in entire to palmately incised leaves or radially veined in peltate leaves; stipules fused, mostly fully amplexicaul; cystoliths present in Poikilospermum, lacking in the other genera. ${ }^{\text {Plants strictly }}$

* Institute of Systematic Botany, Heidelberglaan 2, Uithof, Utrecht, Netherlands. 
dioecious, inflorescences unisexual, the staminate ones cymosely branched, the pistillate ones cymosely branched, capitate, spicate, subumbellate or both staminate and pistillate inflorescences forming a pedunculate digitate cluster of spikes enveloped by a caducous spathe. Staminate flowers with 4-2 free or fused tepals, stamens 4-1, straight in the bud, sometimes inflexed, but then straightening gradually at anthesis; a distinct pistillode mostly lacking. Pistillate flowers with a tubular, 4-2-lobed to 4-2-dentate perianth, ovary free, stigma 1, lingulate to capitate-penicillate to peltate, ovule (sub)orthotropous, basal or subbasal. Fruit small and free or large and either adnate to a fleshy fruiting perianth or free, endocarp crustaceous or woody, endosperm mostly present in small seeds, absent in large seeds, embryo small with flat cotyledons in small seeds, large and with thick cotyledons in large seeds. Light-demanding plants of more or less open vegetations.

\section{THE GENERA OF THE CECROPIACEAE}

\section{Cecropia Loefling}

A genus of probably 70-80 species in tropical America, forming small to tall trees often with stilt-roots; stem and branches with hollow internodes; leaves large, lamina peltate, radially incised, with radial venation; inflorescences a pedunculate digitate cluster of spikes enveloped by a caducous spathe; perianth of staminate and pistillate flowers tubular; stamens 2; stigma capitate-penicillate or peltate, ovule basal; fruit a nutlet, endocarp crustaceous, tuberculate or smooth; endosperm present, cotyledons flat, radicle relatively long.

\section{Musanga R. Brown}

A genus of 2 species in tropical Africa forming trees with stilt-roots; stem and branches with hollow internodes; leaves large, lamina peltate, radially incised, with radial venation; staminate inflorescences repeatedly branched, bearing globose clusters of flowers on the ultimate dichotomies; perianth 2-lobed, stamen 1 ; pistillate inflorescence a clavate, more or less applanate spike; perianth tubular, stigma capitate-penicillate, ovule subbasal; fruit small, endocarp crustaceous, tuberculate; endosperm present, cotelydons flat, radicle relatively long.

\section{Coussapoa Aublet}

A genus of more than $\mathbf{5 0}$ species in tropical America. Usually hemi-epiphytic shrubs or trees with aerial roots or with stilt-roots if terrestrial; leaves with an entire lamina, pinnately veined to subtriplinerved to palmately veined; inflorescences cymosely branched with capitate clusters of flowers on the ultimate dichotomies, in pistillate inflorescences sometimes reduced to a single head; perianth of the staminate flower with 3 , more or less connate tepals, stamens two, either free or entirely connate, or one; perianth of the pistillate flower tubular, stigma capitate-penicillate, ovule basal; fruit small, with a mucilaginous layer outside the verrucate crustaceous endocarp; endosperm scarce (or lacking?), cotyledons flat, radicle relatively long.

\section{Poikilospermum Zipp. ex Miquel}

A genus of 20 species in tropical Asia. Hemi-epiphytic scramblers with aerial roots; lamina entire, mostly pinnately veined, with punctiform or elongate cystoliths; stipules not (fully) amplexicaul. Inflorescences cymosely once or repeatedly branched, with capitate clusters of flowers on the ultimate dichotomies; perianth of the staminate flower with 4-2 free or basally connate tepals, stamens 4-2, straight or inflexed and straightening gradually at anthesis; perianth of the pistillate flower tubular, 4-lobed to 4-dentate, stigma ligulate to capitate-peltate, ovule basal; fruit small, with a mucilaginous layer outside the tuberculate crustaceous endocarp; endosperm scarce or lacking (?), cotyledons rather flat, radicle relatively long. 


\section{Myriantbus Palisot de Beauvois}

A genus of 7 species in tropical Africa. Usually medium-sized trees or shrubs with stilt-roots or sometimes lianas. Leaves with a simple, entire and pinnately veined or with a lobed and palmately veined lamina, or the lamina compound, with 3-7 leaflets; stipules sometimes not fully amplexicaul; staminate inflorescences repeatedly branched, bearing sessile flowers closely set on the ultimate dichotomies or down to more proximal dichotomies; perianth with 4(-3), free or basally connate tepals, stamens $4(-3)$, free or connate; pistillate inflorescences capitate; perianth tubular, 2-3-lobed, stigmas lingulate, ovule basal; fruit large, adnate to the enlarged fleshy perianth, endocarp woody; endosperm lacking, cotyledons thick, radicle short.

\section{Pourouma Aublet}

A genus of probably more than 50 species in tropical America. Small or medium-sized trees, often with stilt-roots; lamina entire or palmately incised, venation pinnate to palmate; inflorescences repeatedly branched, the pistillate ones sometimes subumbellate; staminate flowers often pedicellate and mostly more or less densely glomerate on the ends of the ultimate dichotomies; perianth 4(-3)-lobed to 4(-3)-parted, stamens 4(-3), straight; pistillate flowers usually pedicellate; perianth tubular, entire to $4(-3)$-lobed or $4(-3)$-dentate, stigma (sub)peltate, ovule subbasal to almost lateral; fruit large, free from the enlarged, fleshy perianth, endocarp more or less woody; seed large, endosperm lacking, cotyledons thick, radicle short.

The 6 genera of the Cecropiaceae are two by two very similar in their ecology, habit, and characters of the fruit and seed. Most species of Coussapoa and Poikilospermum are hemi-epiphytes, the species of Cecropia and Musanga are mostly pioneer plants, and most species of Pourouma and Myriantbus are small or medium-sized trees of the lower stories of more or less open and disturbed forests.

Poikilospermum has been revised by Chew Wee-Lek, Gard. Bull. Singapore 20: 1-104. 1963; Musanga and Myriantbus have been revised by de Ruiter, Bull. Jard. Bot. Belg. 46: 471-510. 1976.

\section{KEY TO THE GENERA OF THE CECROPIACEAE}

1. Leaves peltate, their incisions and venation radial.

2. Both staminate and pistillate flowers in spikes arranged in digitate clusters enveloped by a spathe.

Cecropia

2 '. Staminate flowers in capitules on the ultimate dichotomies of branched inflorescences, the pistillate flowers in a more or less applanate spike.

1 '. Leaves entire to (sub)palmate.

Musanga

3. Fruits large (more than $1 \mathrm{~cm}$ long); terrestrial trees or shrubs.

4. Pistillate flowers sessile in a capitate inflorescence; staminate flowers sessile.

Myrianthus

4'. Pistillate flowers pedicellate in branched (or subumbellate) inflorescences; staminate flowers often pedicellate.

Pourouma

$3^{\prime}$. Fruits small (less than $5 \mathrm{~mm}$ long); mostly hemi-epiphytes.

5. Stipules fully amplexicaul; cystoliths absent; stamens 2 or 1 . Coussapoa

$5 '$. Stipules not fully amplexicaul; cystoliths present; stamens 4-2.

Poikilospermum

\section{S UBDIVISION OF THE URTICALES}

The order Urticales is a very natural and clear-cut group without distinct connections with other orders of the dicotyledonous Angiosperms.

The subdivisions of this order, the families Moraceae, Ulmaceae, and Urticaceae of Engler's system (1889), are, on the other hand, not as sharply distinct as 
the order. The close relationships of the subdivisions of the Urticales have been emphasized by most botanists who studied the order or one of its subdivisions.

In Bentham \& Hooker's Genera Plantarum (1880) the Urticales (as Urticaceae) were subdivided into 8 tribes: 1. Ulmeae, 2. Celtideae, 3. Cannabineae, 4. Moreae, 5. Artocarpeae, 6. Conocephaleae, 7. Urticeae, 8. Thelygoneae. The eighth tribe had to be removed from the Urticales. Tribes 1 and 2 became subfamilies of Engler's family Ulmaceae. The tribes 3, 4, 5 and 6 became subfamilies of the Moraceae, whereas the Urticeae constitute the Urticaceae in Engler's system which for a long time was generally adopted. The subfamily Cannaboideae is treated as the family Cannabaceae nowadays, and correctly so, as this taxon is quite distinct, even rather isolated within the Urticales.

The Conocephaloideae were transferred to the Urticaceae by Corner (1962). The Moraceae s. str., thus exclusive of the Conocephaloideae, but still comprising the tribes Artocarpeae and Moreae of Bentham and Hooker's system, appear to form a coherent group of plants, in which only Ficus L. does not show very clear connections with the other members of the family. But this genus is not so isolated as to disrupt the unity of the family.

Chew Wee-Lek (1963) suggested to transfer the microspermous genera Cecropia, Coussapoa, Musanga, and Poikilospermum to the Urticaceae and to leave the megaspermous genera Pourouma and Myrianthus in the Moraceae, thus breaking the unity of the Conocepbaloideae.

For a student of the Moraceae the Ulmaceae look like a distinct and uniform taxon. However, the two subfamilies may be distinct enough to regard them as families, while the Celtoideae appear not to be profoundly distinct from the Moraceae (Grudzinskaya 1967).

\section{COMPARISON OF CHARACTERS}

The Cecropiaceae have several characters in common with the Urticaceae. The pistil with a single stigma and a basal or subbasal orthotropous ovule is urticaceous. This type of pistil can be regarded as derived from the type of pistil (with two stigmas and an apical anatropous ovule) characteristic of the Moraceae and Ulmaceae (cf. Bechtel 1921). In the former family transitions to the urticaceous type of pistil can be found in the rather common reduction of one of the two style branches and the occasional lateral position of the ovule (as in Castilla tunu Hemsl.).

As in the Urticaceae, the system of latex tubes is reduced (Renner 1907; Guérin 1923; Tippo 1938). The plants do not exude milky latex but a mucilaginous sap usually turning black upon exposure to the air. However, some true Urticaceae, e.g. Pouzolzia Gaud. and Laportea Gaud. (cf. Guérin 1923), may exude milky latex! Léandri (1948) did not find laticifers in the herbaceous Fatoua madagascariensis Léandri, which species, as well as $F$. pilosa Gaud., is in many features reminiscent of Urticaceae, but distinctly moraceous in its pistil and fruit.

The type of cystoliths as occurring in the Urticaceae can be found in Poikilospermum (Renner 1907; Chew Wee-Lek 1963), but is lacking in the other five genera of the Cecropiaceae (Renner 1907). Arachnoid hairs as found in the urticaceous genus Boebmeria Jacq. are common in the Cecropiaceae.

In contrast to the Urticaceae, the Cecropiaceae can be characterized as woody and do not even show tendencies towards a herbaceous habit (as the Moraceae do).

The urticaceous type of stamens, inflexed in the bud and bending outward abruptly and elastically at anthesis, does not occur in the Cecropiaceae. Only a few species of Poikilospermum, namely the members of subgenus Poikilospermum, have more or less inflexed stamens, which apparently straighten gradually at anthesis. It has to be noted that inflexed stamens straightening gradually at anthesis (or remain more or less inflexed during anthesis) should be regarded 
as distinct from those bending outward elastically (cf. Berg 1973).

The difference between inflexed and straight stamens has played an important role in delimiting taxa at the rank of family, subfamily or tribe, although many students of (groups of) the Urticales expressed some doubt about the significance of this difference. Corner (1962) dropped the difference as taxonomically unimportant. Corner's broad genus Maclura Nutt. comprises as section the former genus Cudrania Tréc. differing from the other sections of that genus in having straight stamens instead of inflexed ones. Genera placed far from each other in previous systems because of the difference in stamens were put close together in Corner's classification of the Moraceae. It is clear that the difference in stamens has rather little significance in Corner's tribes Artocarpeae and Moreae, which can be united into a single tribe Moreae (cf. Berg 1973). In the Moraceae taxa with inflexed stamens are confined to this tribe (Berg 1977a). On the other hand, inflexed stamens (springing back at anthesis) are a characteristic feature of the Urticaceae. Moreover, the difference in the stamens can be regarded as important with regard to pollination. Inflexed stamens are distinctly connected with wind pollination; the Urticaceae - possibly with a few exceptions - depend on wind as pollinating agent.

Apparent adaptations to wind pollination are missing in the Cecropiaceae, with the probable exception of Cecropia, which shows remarkable morphological adaptations to wind pollination (cf. Berg 1977b). These adaptations can only be expected in an urticalean group in which the stamens are basically straight.

While the Urticaceae are characterized by microspermy, both microspermous and megaspermous genera occur in the Cecropiaceae.

Bisexual inflorescences and monoecious plants are rather common in both Urticaceae and Moraceae. But all species of the Cecropiaceae have unisexual inflorescences and are strictly dioecious.

The leaves are always spirally arranged in the Cecropiaceae, whereas the. Urticaceae (and Moraceae) often bear their leaves in two rows (or less commonly opposite).

Formation of adventitious roots is a characteristic feature of the Cecropiaceae. These roots become stilt-roots in terrestrial taxa and aerial roots in hemiepiphytic genera.

The pollen grains of the Cecropiaceae do not deviate from the common urticalean type (Punt, personal communication).

The features of the secondary wood of the Cecropiaceae in some respects, like the presence of laticifers, resemble the Moraceae more closely than the Urticaceae. Considering the relative diversity of the wood characters of the Moraceae, the Cecropiaceae could be placed in the Moraceae on the basis of their wood structure (A.M.W. Mennega, personal communication).

\section{CONCLUSION}

Corner's decision to remove the Conocephaloideae from the Moraceae was correct. But by placing this taxon in the Urticaceae he strongly reduced the uniformity and unity of this family.

The group of 6 genera which constituted the Conocepbaloideae is quite distinct from the Moraceae, although it shows some, but not very pronounced, similarities to the Moraceae in vegetative characters. It is closely related to the Urticaceae, considering the similarities in the pistil and the reduced system of latex tubes. But it is not much closer to the Urticaceae than this family is to the Moraceae. Some genera of the Moraceae, like Fatoua and, to a lesser degree, the monotypic neotropical genus Poulsenia Eggers, show chiefly vegetative similarities and transitions to the Urticaceae.

The 6 genera appear to form a very natural, coherent group, which merits a rank equal to that of the Moraceae and the Urticaceae. To recognize the Moraceae s. str., the Urticaceae s. str., and the Conocepbaloideae as subfamilies of a 
broad family Urticaceae (cf. Berg 1973), would be an acceptable solution, but not a very practical one. It would certainly open the question whether the Ulmaceae could not also be inserted in such a broadly construed family, and consequently the limits of this family could co-incide with the limits of the order.

A better solution appears to be to return to Bentham and Hooker's subdivisions of the (Urticaceae $\Rightarrow$ ) Urticales, leaving however, the Artocarpeae and Moreae together in one family, the Moraceae, and the Ulmeae and Celtideae provisionally in a single family. (cf. Grudzinskaya 1967).

\section{KEY TO THE FAMILIES OF THE U RTICALES}

1. Ovule apical (to lateral) and anatropous; style usually bifid.

2. Plants without latex; stamens straight.

3. Arborescent plants.

Ulmaceae

3 '. Herbaceous plants.

Cannabaceae

$2^{\prime}$ Plants with latex (except the herbaceous Fatoua); stamens straight or inflexed.

1 '. Ovule basal or subbasal, (sub)orthropous; style unbranched.

4. Stamens straight in the bud, sometimes inflexed but not bending outward elastically; plants arborescent.

Cecropiaceae

4.' Stamens inflexed in the bud and bending outward elastically; plants herbaceous or woody.

Urticaceae

\section{AKNOWLEDGEMENTS}

The author is much indebted to Dr. K.U. Kramer (Zürich) for correcting the English text and contributing the Latin diagnosis, and to Dr. A. Cronquist (New York), Dr. J. Cuatrecasas (Washington), and Dr. R. Thorne (Claremont) for discussions on the subject of this paper during his visit to the United States supported by the Netherlands Organization for Advancement of Pure Research (Z.W.O.).

\section{References}

Bentham, G. \& J. D. Hooker 1880 - Genera Plantarum 3 (1). Urticaceae: 341-395. London.

BECHTEL, A. R. 1921 - The floral anatomy of the Urticales. Amer. J. Bot. 8: 386-410.

BERG, C. C. 1973 - Some remarks on the classification and differentiation of the Moraceae. Meded. Bot. Mus. Herb. Utrecht. No. 386.

BERG, C. C. $1977 \mathrm{a}$ - The Castilleae, a tribe of the Moraceae, renamed and redefined due to the exclusion of the type genus Olmedia from the "Olmedieae". Acta Bot. Neerl. 26: 73-82.

BERG, C. C. 1977b - Abscission of anthers in Cecropia Loefl. Acta Bot. Neerl. 26: 00-00.

CHEW WE E-LEK, 1963 - A revision of the genus Poikilospermum. Gard. Bull. Singapore 20 1-104.

CORNER, E. J.H. 1962 - The classification of Moraceae. Gard. Bull. Singapore 19: 187-252.

ENGler, G. H. A. 1889 - In Engler \& Prantl, Die natürlichen Pflanzenfamilien 3(1). Ulmaceae - Moraceae - Urticaceae: 59-118. Leipzig.

GRUDZINSKA'YA, I. A. 1967 - Ulmaceae and reasons for distinguishing Celtoideae as a separate family Celtidaceae Link. Bot. Zurn. (Moscow \& Leningrad) 52: 1723-1749.

GUER IN, P. 1923 - Les Urticées: cellules à mucilage, laticifères et canaux sécréteurs. Bull. Soc. Bot. France 70: 125-136, 207-215, 255-263.

LÉANDR1, J. 1948 - Contribution à l'étude des Moracées de Madagascar (Moroideae). Mem. Inst. Sci. Madag. B. 1: 1-37.

RENNER, O. 1907 - Beiträge zur Anatomie und Systematik der Artocarpeen und Conocephaleen, insbesondere der Gattung Ficus. Bot. Jahrb. 39: 319-448.

TIPPO, O. 1938 - Comparative anatomy of the Moraceae and their presumed allies. Bot. Gaz. 100: 1-99. 